\title{
Who Chooses Teaching and Why? Profiling Characteristics and Motivations Across Three Australian Universities
}

\author{
Paul W. Richardson ${ }^{\mathrm{a}}$ and Helen M. G. Watt ${ }^{\mathrm{b} \dagger}$ \\ ${ }^{\mathrm{a}}$ Monash University, Australia; ${ }^{\mathrm{b}}$ University of Michigan, USA \\ ${ }^{\dagger}$ Ordering of names is alphabetical for equal first authors
}

In this large-scale Australian study, we profile the background characteristics and teaching motivations for individuals entering teacher education across three major established urban teacher provider universities in the Australian States of New South Wales and Victoria. Our recently developed and validated "FIT-Choice" (Factors Influencing Teaching Choice) Scale determines the strength of influence for a range of motivations from individuals choosing teaching as a career. Findings build upon and extend previous literature relating to reasons for teaching as a career choice, which have not systematically applied current motivational models to developing explanations. Participants were the entire cohorts $(N=1,653)$ of first-year pre-service teacher education candidates at three universities in Sydney and Melbourne. Results provide a profile of a large sample of pre-service teachers whose decision to enrol in a teacher education program has been made at a time when the mass media and the general public have increasingly looked upon teaching as a poor career choice. Our new theoretical approach allows us to recommend strategies for teacher recruitment campaigns, based on a comprehensive understanding of individuals' motivations for choosing teaching.

\section{Introduction}

It is often taken as self-evident that teachers can and do make a difference by influencing the lives of children and adolescents and their orientation to learning. Equally, it has been acknowledged by Governments around the world that quality teachers and teaching are central to the development and maintenance of an intelligent, informed citizenry. For example, Australian ministers of education

Correspondence to: Paul W. Richardson, Faculty of Education, Monash University, Clayton Campus, Melbourne, VIC 3800, Australia. Email: paul.richardson@education.monash.edu.au; or Helen M. G. Watt, now also located at Monash University. Email: helen.watt@education.monash. edu.au 
affirmed this sentiment in The Adelaide declaration on national goals for schooling in the twenty-first century (MCEETYA, 1999), by acknowledging the key role that teachers play in developing future Australian citizens, highlighting their contribution to social capital and the essential social infrastructure of the country:

Australia's future depends upon each citizen having the necessary knowledge, understanding, skills and values for a productive and rewarding life in an educated, just and open society. High quality schooling is central to achieving this vision (available online at http://www.mceetya.edu.au/nationalgoals/natgoals.htm).

Although teaching would therefore appear to be a socially valued occupation, Australia, the US, the UK and a number of European countries are currently experiencing difficulties in attracting and maintaining effective teachers (see Liu, Kardos, Kauffman, Preske, \& Johnson, 2000; OECD, 2004; Preston, 2000). This is so in particular disciplinary areas in secondary schools such as mathematics, science, computer sciences, technology and foreign languages; and also in early childhood where salary scales are less than rewarding. Although there is a lack of reliable empirical evidence from the Australian states and territories, figures from the US and the UK show that one in five teachers will leave the profession within three years of entry (Henke, Chen, \& Geis, 2000; Johnson \& Birkeland, 2003; Ofsted, 2001). Of all the teachers who participated in the Third International Mathematics and Science Study (TIMSS) (Lokan, Ford, \& Greenwood, 1996), the highest proportion of teachers indicating that they would "prefer to change to another career" (p. 197) were from Australia and New Zealand.

Coincident with these developments, the teaching force is ageing in many of these countries, including Australia where by 1999, 39\% of teachers were in the 41-50 age group (MCEETYA, 2002), and by 2001 the median age of teachers was 43, with $44 \%$ older than 45 (DEST, 2003). Similarly, in some European Union countries, half the teaching force is aged over 40 (European Commission, 2000). As these older teachers retire, the problem of teacher shortages is projected to escalate and to critically impact on those areas experiencing the greatest shortages; as well as hardto-staff schools in rural and urban areas.

At the same time as teaching must compete with other careers and professions for new entrants, its appeal as a career is declining (see Ramsay, 2000), with teachers being asked to do more work for less reward. Relative to other professions, teaching salaries are falling-despite the increased demands being placed on teachers (Liu et al., 2000; OECD, 2004; Ramsay, 2000). There is growing concern about whether there will soon be enough teachers, although the immediate effect of the shortage may more likely be a lowering of the quality of teachers, as qualification requirements are relaxed or ignored in order to meet the demand. An alternative or additional scenario could be a lowered quality of teaching, as workloads and class sizes are increased to accommodate teacher shortfalls (see Santiago, 2001). Paralleling and perhaps anticipating these developments, the Australian Government and the State and Territory Governments have put in place at the local level The National Framervork 
for Professional Standards for Teaching, a program endorsed by MCEETYA in July 2003. How these competing demands will be played out remains to be seen.

Australian universities offer teacher education in both graduate and undergraduate modes. The graduate degree or diploma typically involves one year full time preparation (or equivalent part time), and sometimes two years (see Skilbeck \& Connell, 2003). This therefore produces teachers in a much reduced timeframe, relative to the four to five years for undergraduate teacher education degrees. Australian universities are responding to the demand for teachers by ensuring that they have firm numbers undertaking graduate diplomas and degrees. In the case of one university we studied, the University of Western Sydney, teacher preparation has now become only available through the graduate mode. In another, the University of Sydney, although the postgraduate diploma of education mode was abandoned in the 1990s, a new model of graduate education in the form of the Master of Teaching qualification was subsequently introduced. Our third university, Monash University, has maintained a commitment to both modes of teacher education following the introduction of undergraduate degrees during the 1990s.

"Career switcher" entrants to the graduate mode of teacher education have been suggested to be more mature and professional, to be more committed to their choice of teaching as a career, to have developed a well-defined sense of themselves in their previous careers, and to possess people skills germane to teaching (Freidus, 1992; Haipt, 1987/1988; Novak \& Knowles, 1992; Resta, Huling, \& Rainwater, 2001). Even with these potentially valuable skills, experiences and knowledge, the move into teaching is not a seamless transfer from previous occupations for career switchers. They often struggle with their attitudes and beliefs about teaching, preconceived notions of the nature of teaching and learning, and the need to learn pedagogical strategies (Bullough Jr. \& Knowles, 1990; Crow, Levine, \& Nager, 1990; Freidus, 1992; Ludwig, Stapleton, \& Goodrich, 1995; Powell, 1996). Research to date regarding career switchers has focused on small and opportune groups. Further studies are needed, particularly with large-scale and representative cohorts to empirically contrast the background characteristics, teaching motivations, perceptions about the profession, and career commitment and satisfaction for undergraduate and graduate teacher education entrants.

Unless teaching can be made an attractive career choice for new graduates as well as for those who switch to teaching after pursuing other careers (Crow et al., 1990; Priyadharshini \& Robinson-Pant, 2003; Richardson \& Watt, 2005; Serow \& Forrest, 1994) the shortage of suitably qualified and experienced teachers promises to worsen. If policy-makers are to effectively attract suitably qualified people into the profession, they will need to understand whether career change entrants have complex reasons for seeking to switch careers, and that these motivations may contrast with the entry motivations of undergraduate school-leavers commencing teacher education studies.

Teaching has long attracted substantial numbers of women. Comparative figures show that in the US in 1978, 67.1\% of all elementary and secondary teachers were 
women (Ornstein \& Miller, 1980), while in Australia in 1979 the proportion was $56 \%$. Just 20 years later the Australian figure had risen to $65 \%$. The number of men teaching in primary schools in particular continues to decline, and there has been a growing debate about the desirability of this trend (DEST, 2003). Government ministers and members of the Australian Labor Party have reached bipartisan agreement by asserting the need to bring more males into the teaching profession, to provide positive role models for young boys, especially in their primary school years. However, findings from Government commissioned reviews examining the educational needs of boys (House of Representatives Standing Committee on Education and Training, 2002; Lingard, Martino, Mills, \& Bahr, 2002; Martin, 2002) have been received amidst the jingle-jangle of charged political debate and opinion pieces about the presumed educational benefits accruing to boys from male teachers.

If policy-makers and employing authorities wish to redress the current gender imbalance among teachers, then it is essential to understand that men and women have different factors motivating them to pursue teaching (Watt \& Richardson, in review). The gender imbalance in the profession has been in part attributed to the lower salaries of teachers relative to average salaries, especially for men. Existing recruitment practices are also limited in their scope, focusing overwhelmingly on teachers' potential to make a social contribution, and neglecting other important motivations, which may lead to selective targeting of new entrants to the profession (see Santiago, 2001). A notable exception has been the recent "Use your head" campaign run by the Teacher Training Agency in the UK in 2004, developed in parallel with our findings that individuals' perceived teaching-related abilities were a prominent factor in influencing their decision to teach (Richardson \& Watt, 2003; Watt \& Richardson, 2003). That campaign portrayed teaching as an intellectually demanding, cognitively stimulating career that enables individuals to realize their talents and abilities.

In order to improve recruitment efforts, it is critical to target the range of motivations that attracts people to the teaching profession. From the 1960s through to the $1990 \mathrm{~s}$ a number of themes were identified in the predominantly North American literature: the desire for social mobility, the influence of parents and extended family, time compatibility, the need for a stimulating absorbing career, an ability to influence others, the desire to work with young children and adolescents, to work in a people-oriented profession, and job-related benefits such as security, pensions and vacations. While we would expect some commonalities with these motives in the Australian context in the twenty-first century, earlier explanations may no longer be adequate or entirely relevant.

The multidimensional character of the teacher's role at this historical point in time has amplified the complexity of the skills set that teachers now need in order to be effective across diverse sociocultural contexts in schools and communities. This skills set now embraces social, behavioural, civic, economic and technological dimensions. Within the multicultural context of a country like Australia, particularly in the largest cities of Sydney and Melbourne, the teacher's role is also likely to require 
engagement with families and communities holding values and beliefs from a diversity of cultures and cultural backgrounds.

The changed role of teachers has not been adequately reflected in the extant literature, and may well clash with entry motivations based simply on the desire to work with children for example. At the level of the State, there is also mounting pressure to regulate the nature and quality of teachers' work through teacher certification and re-certification, placing new demands on teachers. Ironically, as these regulation processes are being put in place, many politically conservative Governments around the world are insisting that the public sphere be progressively more subject to market forces and privatization (Beck, 2000). This is especially evident in relation to essential services such as public transportation, medical and hospital care, and management of the environment.

The current literature is unclear on why people choose teaching careers and why many leave the profession in their early years, is predominantly empirically rather than theoretically driven, and has generally failed to draw on the motivation literature. Prior research has lacked an integrative theoretical framework to guide the selection and organization of influential factors, proceeded in a somewhat piecemeal fashion using poorly defined constructs, and with individual researchers frequently investigating subsets of possible factors. Our "FIT-Choice" (Factors Influencing Teaching Choice) framework provides a comprehensive and coherent model to guide systematic investigation into this problem.

\section{The "FIT-Choice" Framework}

The FIT-Choice ("Factors Influencing Teaching Choice") framework, founded on expectancy-value theory, was developed by Watt and Richardson (Watt \& Richardson, in review) to provide a comprehensive and coherent model to guide systematic investigation into the question of why people choose a teaching career (see Figure 1). To date, this research has also not been strongly articulated with the extant motivation literature, nor the career choice literature more generally. Our model draws together recurring themes from the teacher education literature that have been identified in relation to teaching career choice, alongside ability-related beliefs emphasized in the broad career choice literature. We locate these themes within the Expectancy-Value framework, the most comprehensive motivational model for explaining academic and career choices (Wigfield \& Eccles, 2000). Although initially developed as a framework for explaining students' choices for math participation (Eccles (Parsons), Adler, Fuuterman, et al., 1983), the Eccles et al. Expectancy-Value model has since been fruitfully applied to other academic school disciplines, as well as to choices to participate in specific types of careers (for example, Watt, 2002), and is valuable for guiding investigations into teaching as a career choice.

Our framework taps both the "altruistic"-type motivations which have been emphasized in the teacher education literature (see Book \& Freeman, 1986; Brown, 
1992; Lortie, 1975; Moran, Kilpatrick, Abbott, Dallatt, \& McClune, 2001; Serow \& Forrest, 1994) as well as more personally utilitarian motivations and intrinsic motivations, together with ability-related beliefs which are the focus of the broader career choice literature (see Lent, Lopez, \& Bieschke, 1993). Our framework also taps individuals' perceptions about the demand and reward aspects of the teaching profession, and contains a measure of career satisfaction and commitment. We have provided a review elsewhere (Watt $\&$ Richardson, in review) of how our FIT-Choice factors, summarized in Figure 1, map to Expectancy-Value theory, Social Cognitive Career Theory, and key findings within the teacher education literature.

In brief, our model contains antecedent "socialization influences", followed by more proximal influences of "task perceptions", "self perceptions", "values", and "fallback career". Higher order task demand and return constructs in turn contain first-order constructs: "expertise" and "difficulty" comprise the higher order "task demand" construct; and "social status and teacher morale" and "salary" comprise the higher order "task return" construct. Similarly, higher order "values" constructs contain first order component constructs. Values constructs in our model are "intrinsic value", "personal utility value" and "social utility value". The last two values constructs contain component first-order constructs: "job security", "time for family", and "job transferability" comprise "personal utility value"; and "shape future of children/adolescents", "enhance social equity", "make social contribution" and "work with children/adolescents" comprise the higher-order "social utility

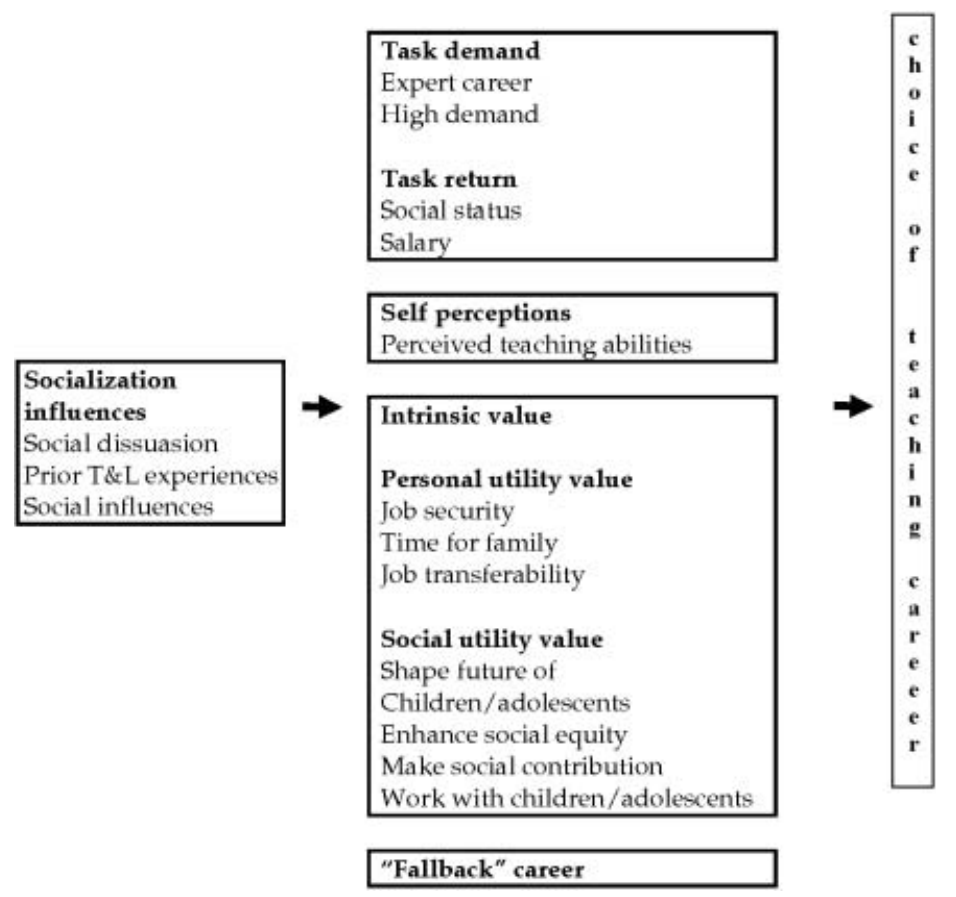

Figure 1. The "FIT-Choice" framework: Motivations for choosing a teaching career 
value" construct. Our FIT-Choice scale items which tap each construct are presented in Table 1.

\section{The Present Study}

The scope of our study goes beyond the provinces of previous smaller-scale studies. In the present study, we apply our FIT-Choice scale to teacher education entrants across three Australian universities, each of which is a major teacher education provider impacting on the supply of teachers in their respective States. In surveying all consenting entrants to teacher education at these three universities, we represent both undergraduate and graduate teacher education modes, as well as secondary, primary and early childhood strands. Our findings provide a profile of intending teachers for each of the universities, addressing entrants' demographic characteristics, teaching motivations, perceptions about the profession, and career commitment and satisfaction. We consider the extent of differences and similarities across the three universities, and contrast the backgrounds, motivations and career choice satisfaction for undergraduate and graduate teacher education candidates.

\section{Method}

\section{Sample and Setting}

Participants $(N=1,653)$ were enrolled in teacher education programs at three Australian universities - selected because they are large teacher education providers (in the Eastern Australian States of New South Wales, NSW, and Victoria). The University of Sydney in NSW was Australia's first university, founded in 1850. It is a member of the "Group of Eight" of Australia's major research intensive universities, and attracts notably high levels of first-preference selections into all courses. Monash University (in Victoria) was established in 1958 and has grown from a single campus at Clayton to six campuses in Australia, one in Malaysia and one in South Africa. It characterizes itself as Australia's most internationalized university, and is also a member of the "Group of Eight". As such, it has similarly high levels of firstpreference selections for teacher education. The University of Western Sydney (UWS) is a newly established multi-campus university. In recent years this University's key priorities have included strategies to develop its research capability. With over 1000 teacher education graduates each year, UWS provides the largest number of secondary, primary and early childhood teachers in NSW and is one of the largest providers of beginning teachers in Australia.

All three universities offer teacher education degrees at both the undergraduate and graduate levels. ${ }^{2}$ At the undergraduate level, secondary teacher education at the University of Sydney is a five-year full time "combined" degree, where candidates graduate with their secondary teaching qualification in combination with a Bachelor of Arts, Science or Economics, for example. At Monash University, it is a four-year 
Table 1. Final empirically validated "FIT-Choice" subscales and items

\begin{tabular}{|c|c|c|c|c|}
\hline Higher-order factor & Factor & Item \# & & Anchors \\
\hline & & & Part B: Influential factors & \\
\hline & & & Item stem: "I chose to become a teacher because..." & \\
\hline \multirow[t]{3}{*}{$\mathrm{N} / \mathrm{A}$} & Ability & B5 & I have the qualities of a good teacher & 1 (not at all important), to 7 \\
\hline & & B19 & I have good teaching skills & (extremely important) \\
\hline & & $\mathrm{B} 43$ & Teaching is a career suited to my abilities & \\
\hline \multirow[t]{3}{*}{ N/A } & Intrinsic career value & $\mathrm{B} 1$ & I am interested in teaching & \\
\hline & & $\mathrm{B} 7$ & I've always wanted to be a teacher & \\
\hline & & B12 & I like teaching & \\
\hline \multirow[t]{3}{*}{ N/A } & Fallback career & B11 & I was unsure of what career I wanted & \\
\hline & & B35 & I was not accepted into my first-choice career & \\
\hline & & B48 & I chose teaching as a last-resort career & \\
\hline \multirow[t]{11}{*}{ Personal utility value } & Job security & B14 & Teaching will offer a steady career path & \\
\hline & & $\mathrm{B} 27$ & Teaching will provide a reliable income & \\
\hline & & B38 & Teaching will be a secure job & \\
\hline & Time for family & $\mathrm{B} 2$ & Part time teaching could allow more family time & \\
\hline & & B16 & $\begin{array}{l}\text { Teaching hours will fit with the responsibilities of having a } \\
\text { family }\end{array}$ & \\
\hline & & B29 & School holidays will fit in with family commitments & \\
\hline & & B4 & As a teacher I will have lengthy holidays & \\
\hline & & B18 & As a teacher I will have a short working day & \\
\hline & Job transferability & B8 & Teaching will be a useful job for me to have when travelling & \\
\hline & & $\mathrm{B} 22$ & A teaching qualification is recognised everywhere & \\
\hline & & $\mathrm{B} 45$ & A teaching job will allow me to choose where I wish to live & \\
\hline
\end{tabular}


Table 1. (continued)

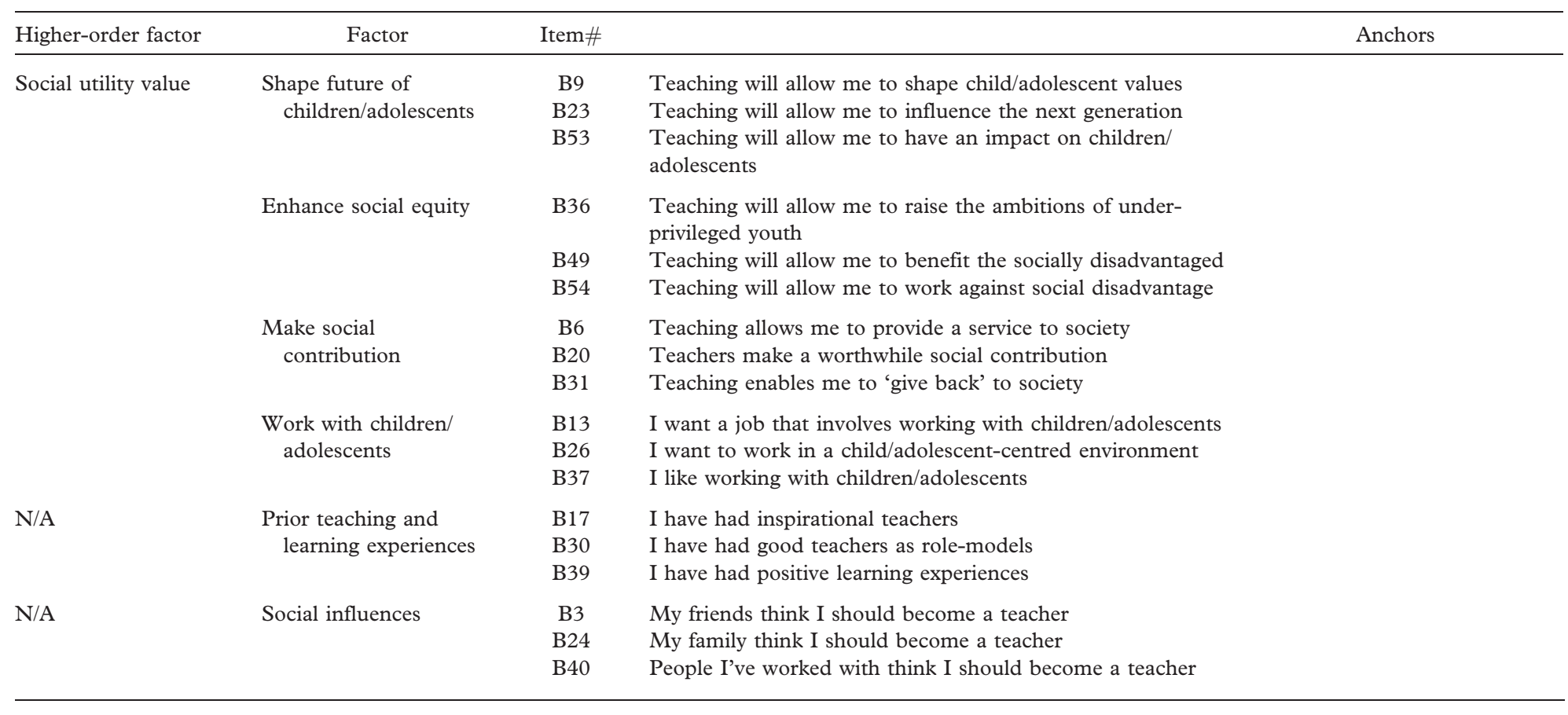


Table 1. (continued)

\begin{tabular}{|c|c|c|c|c|}
\hline Higher-order factor & Factor & Item \# & & Anchors \\
\hline & & & Part C: Beliefs about teaching & \\
\hline \multirow[t]{6}{*}{ Task demand } & \multirow[t]{3}{*}{ Expertise } & C10 & $\begin{array}{l}\text { Do you think teaching requires high levels of expert } \\
\text { knowledge? }\end{array}$ & \multirow[t]{6}{*}{1 (not at all), to 7 (extremely) } \\
\hline & & $\mathrm{C} 14$ & $\begin{array}{l}\text { Do you think teachers need high levels of technical } \\
\text { knowledge? }\end{array}$ & \\
\hline & & C15 & Do you think teachers need highly specialised knowledge? & \\
\hline & \multirow[t]{3}{*}{ Difficulty } & $\mathrm{C} 2$ & Do you think teachers have a heavy workload? & \\
\hline & & $\mathrm{C} 7$ & Do you think teaching is emotionally demanding? & \\
\hline & & C11 & Do you think teaching is hard work? & \\
\hline \multirow[t]{9}{*}{ Task return } & \multirow[t]{6}{*}{ Social status } & $\mathrm{C} 4$ & Do you believe teachers are perceived as professionals? & \\
\hline & & C8 & $\begin{array}{l}\text { Do you believe teaching is perceived as a high-status } \\
\text { occupation? }\end{array}$ & \\
\hline & & $\mathrm{C} 12$ & Do you believe teaching is a well-respected career? & \\
\hline & & C5 & Do you think teachers have high morale? & \\
\hline & & C9 & Do you think teachers feel valued by society? & \\
\hline & & C13 & $\begin{array}{l}\text { Do you think teachers feel their occupation has high social } \\
\text { status? }\end{array}$ & \\
\hline & \multirow[t]{3}{*}{ Salary } & $\mathrm{C} 1$ & Do you think teaching is well paid? & \\
\hline & & C3 & Do you think teachers earn a good salary? & \\
\hline & & & Part D: Your decision to become a teacher & \\
\hline \multirow[t]{3}{*}{ N/A } & \multirow[t]{3}{*}{ Social dissuasion } & D2 & Were you encouraged to pursue careers other than teaching? & \multirow{6}{*}{1 (not at all), to 7 (extremely) } \\
\hline & & $\mathrm{D} 4$ & Did others tell you teaching was not a good career choice? & \\
\hline & & D6 & $\begin{array}{l}\text { Did others influence you to consider careers other than } \\
\text { teaching? }\end{array}$ & \\
\hline \multirow[t]{3}{*}{ N/A } & \multirow{3}{*}{$\begin{array}{l}\text { Satisfaction with } \\
\text { choice }\end{array}$} & D1 & How carefully have you thought about becoming a teacher? & \\
\hline & & D3 & How satisfied are you with your choice of becoming a teacher? & \\
\hline & & D5 & How happy are you with your decision to become a teacher? & \\
\hline
\end{tabular}

Do you think teachers have high morale?

Do you think teachers feel their occupation has high social status? 
full time combined degree, while at UWS, it is a four-year full time single degree. Undergraduate primary teacher education is a four-year full time degree at each of the three universities, and only at Monash is it a "combined" degree. Undergraduate early childhood teacher education is offered at Monash and UWS, and is also a four-year full time degree, which is again a "combined" degree at Monash. The University of Sydney previously offered an undergraduate early childhood teacher education degree but this was phased out in the late 1980s.

At the graduate level, the University of Sydney offers a two-year full time Master of Teaching (MTeach) qualification in both secondary and primary teacher education strands. It is possible for candidates to exit the degree after 18 months with a Bachelor of Teaching (BTeach) although few individuals elect to take this pathway. Monash University offers a one-year full time Graduate Diploma in Education (Grad. Dip. Ed.) in secondary and primary teacher education strands. This degree is also available in flexible distance and evening part time modes, although those candidates were not sampled for the present study. UWS also offers a one-year full time or 18-month part time Bachelor of Teaching (BTeach) degree, again in secondary and primary teacher education strands.

All commencing teacher education candidates were invited to participate in the study from the three universities, excluding secondary education part time distance education and evening candidates at Monash University, which was the only one of the three universities having these modes. High response rates, ranging from 75$89 \%$, imply that our findings represent the population characteristics for each of the three universities (see Table 2).

\section{Measures}

\section{Teacher Education Candidate Characteristics}

Participants checked boxes to indicate their gender (male or female), undergraduate or graduate enrolment, and degree (secondary, primary or early childhood ${ }^{3}$ teacher education). They also indicated their parents' combined income from when they were in high school as an indicative measure for background socioeconomic status (SES). Income categories included were $\$ 0-30,000, \$ 30,001-60,000, \$ 60,001-$ $90,000, \$ 90,001-120,000, \$ 120,001-150,000, \quad \$ 150,001-180,000, \quad \$ 180,001-$ $210,000, \$ 210,001-240,000$, and $\$ 240,000$ or above. Participants also nominated their age in years, the language mainly spoken at home, and the countries in which each of their parents had been born.

Table 2. Undergraduate and graduate participant response rates at each university

\begin{tabular}{lcc}
\hline & Undergraduate & Graduate \\
\hline USyd $(N=488)$ & $88 \%$ & $77 \%$ \\
Monash $(N=508)$ & $75 \%$ & $84 \%$ \\
UWS $(N=657)$ & $89 \%$ & $85 \%$ \\
\hline
\end{tabular}




\section{“Career Switcher" Backgrounds}

Graduate entrants who indicated that they had previously pursued another career were asked to list details of that career. These prior careers were classified in terms of their occupational status using $\mathrm{O}^{\star} \mathrm{NET}$ - a comprehensive database of occupational information provided by the US Department of Labor (US Department of Labor Employment and Training Administration, 1998). Each occupation in the database is ranked from 1 through 5 for its occupational status, derived from such factors as average salary and amount of educational preparation and training required. Teaching was classified as " 4 " on the five-point scale, along with careers including academia, accountancy, banking, clinical psychology, computer programming, engineering, graphic design, journalism, marketing, nursing, pharmacy and publishing.

Other careers were coded as either "lower", "same" or "higher" status than teaching, based on $\mathrm{O}^{\star} \mathrm{NET}$ indicators. Example careers that scored the lowest occupational status of " 1 " included café work, call centre work, childcare and landscaping. Second lowest with a score of " 2 " were air host/essing, alternative therapies, office work, retail sales and secretarial work. The category of " 3 "- one category below teaching - included actor, animal technician, architectural draftsperson, dental technician, electrician, hospitality personnel, performing artist, personal trainer, photographer, police officer, professional athlete, travel consultant and written translator. The highest category of " 5 " included careers such as aeronautical engineer, biotechnologist, business manager, chemical engineer, classical musician, dentist, environmental scientist, geologist, lawyer and medical doctor.

\section{Motivations for Teaching}

Participants' motivations for choosing teaching as a career were assessed using our FIT-Choice scale (for full details about the scale and information on good construct reliability and validity with this sample see Watt $\&$ Richardson, in review). These motivations are presented as part of Figure 1 and include intrinsic values, personal utility values (job security, time for family, job transferability), social utility values (shape future of children/adolescents, enhance social equity, make social contribution, work with children/adolescents), self perceptions of individuals' own teaching abilities, the extent to which teaching had been a "fallback" career choice, social influences, and prior positive teaching and learning experiences. Each factor was measured by multiple item indicators with response options ranging from 1 (" not at all important") through 7 ("extremely important"). A preface to all motivation items in the scale was "I chose to become a teacher because ...", which was typed in large boldfaced font at the top of each page.

\section{Perceptions about the Profession}

Participants also rated the extent of their agreement with a number of propositions about the teaching profession, with response options ranging from 1 ("not at all") 
through 7 ("extremely"). Multiple propositions together comprised factors relating to the extent to which respondents perceived teaching as high in task demand (expert career, high demand), and as high in task return (social status, salary).

\section{Career Choice Satisfaction}

Participants' career choice satisfaction was measured by three items with response options from 1 ("not at all") through 7 ("extremely"). As part of this section, participants also rated the extent to which they had experienced social dissuasion from teaching as a career choice.

\section{Procedure}

Surveys were conducted early in the academic year-2002 at the University of Sydney and 2003 at both Monash University and the University of Western Sydney. They were administered in tutorial class groups to enhance data integrity and allow for clarification of respondent queries. Administration was by the researchers and two trained assistants, with University ethics approval, consent of program coordinators, and informed consent of all participants. It took approximately 20 minutes for participants to complete the survey.

\section{Analyses}

Initial background profiles for each university summarized degree enrolments and proportions of females relative to males within each enrolment strand. Tabulated frequencies described enrolments within each of undergraduate and graduate secondary, primary and early childhood teacher education strands, while percentages summarized the proportion of females within each strand. Age profiles were developed for undergraduates and graduates within each university, represented using box plots. Indicative SES profiles were also created, based on participantreported combined parental income, again represented using box plots for undergraduates and graduates within each university. Ethnic background profiles were described by percentages for undergraduates and graduates within each university, for each of language mainly spoken at home, and parent countries of birth.

For the subset of graduate participants who indicated that they had pursued a previous career, bar charts displayed the percentages of those people who had listed each career type, separately within each university. To describe the occupational status of those previously pursued careers relative to teaching, histograms summarized the percentages of people who had switched careers into teaching from each of lower, the same, or higher occupational statuses.

Motivations for choosing teaching as a career, perceptions about the teaching profession, and career choice satisfaction were summarized by mean scores on each 
factor, for undergraduates and graduates within each university, and displayed using histograms. Analyses of variance (ANOVAs) subsequently tested for statistically significant differences between undergraduate and graduate participants across factors, separately within each university. Alpha was set at 0.01 in view of the sample size.

\section{Results}

\section{Who Chooses Teaching?}

University enrolment profiles. All three universities had large enrolments for teacher education entrants, and high response rates signify that our findings provide reliable summaries for each university (see Table 2). The enrolment numbers for undergraduate and graduate participants within each of the secondary, primary and early childhood teacher education strands are shown in Table 3 where it can be seen that there are some differences in the enrolment distributions across the universities. The University of Sydney had the greatest enrolment in secondary teacher education, did not offer early childhood teacher education, and had substantially more undergraduate than graduate enrolments. Monash and UWS had almost three times as many graduate teacher education students relative to undergraduate enrolments in secondary teacher education, while the pattern was reversed for primary teacher education, where there were approximately double the numbers of undergraduates relative to graduates. For Monash and UWS, who offered early childhood teacher education through the undergraduate degree mode, Monash had only a small early childhood cohort, and UWS had a cohort twice that size. Of the three universities, UWS had the greatest number of total enrolments.

Gender representation. Enrolments within each teacher education strand were largely female dominated (see Table 4). This was most marked for early childhood teacher education, where enrolments were almost exclusively female. Primary teacher education had the next highest concentration of females, both for undergraduate and graduate candidates. While secondary teacher education contained lower proportions of females than either primary or early childhood teacher education, well over half the enrolments were still female at each university.

Table 3. Teacher education strands in the sample

\begin{tabular}{lcccc}
\hline & $\begin{array}{c}\text { Secondary N's } \\
\text { UG/Grad }\end{array}$ & $\begin{array}{c}\text { Primary N's } \\
\text { UG/Grad }\end{array}$ & $\begin{array}{c}\text { E.C. N's } \\
\text { UG/Grad }\end{array}$ & $\begin{array}{c}\text { Totals N's } \\
\text { UG/Grad }\end{array}$ \\
\hline USyd & $195 / 122$ & $103 / 68$ & $n / a$. & $298 / 190$ \\
Monash & $72 / 212$ & $119 / 68$ & $37 / n / a$. & $228 / 280$ \\
UWS & $68 / 197$ & $218 / 91$ & $83 / n / a$. & $369 / 288$ \\
Totals & $335 / 531$ & $440 / 227$ & $120 / n / a$. & $895 / 758$ \\
\hline
\end{tabular}


Table 4. Proportional female representation within teacher education strands

\begin{tabular}{lcccc}
\hline $\begin{array}{c}\text { Secondary \% female } \\
\text { UG/Grad }\end{array}$ & $\begin{array}{c}\text { Primary \% female } \\
\text { UG/Grad }\end{array}$ & $\begin{array}{c}\text { E.C. \% female } \\
\text { UG/Grad }\end{array}$ & $\begin{array}{c}\text { Totals \% female } \\
\text { UG/Grad }\end{array}$ \\
\hline USyd & $71 / 66$ & $89 / 82$ & $n / a$ & $77 / 72$ \\
Monash & $59 / 69$ & $73 / 85$ & $97 / n / a$ & $72 / 73$ \\
UWS & $57 / 60$ & $88 / 83$ & $94 / n / a$ & $84 / 67$ \\
\hline
\end{tabular}

Age profiles. Age profiles differed across undergraduates and graduates and across the three universities (see Figure 3). Not surprisingly, undergraduates tended to be younger than graduates. The median undergraduate age in years in the first year of enrolment was 19 at both the University of Sydney and Monash University, and 20 at UWS. Undergraduates at the University of Sydney had the most clustered ages (with the interquartile range spanning 18 to 20 years), followed by Monash (interquartile range from 18 to 22 years), while undergraduates at UWS showed the greatest diversity in ages (interquartile range from 18 to 24 years). Median graduate ages appeared similar across the universities - 25 years at the University of Sydney, and 26 years at each of Monash and UWS. Age distributions were more widely spread than for undergraduates, with the University of Sydney again showing the least (interquartile range from 23 to 29 years) and UWS the most diversity

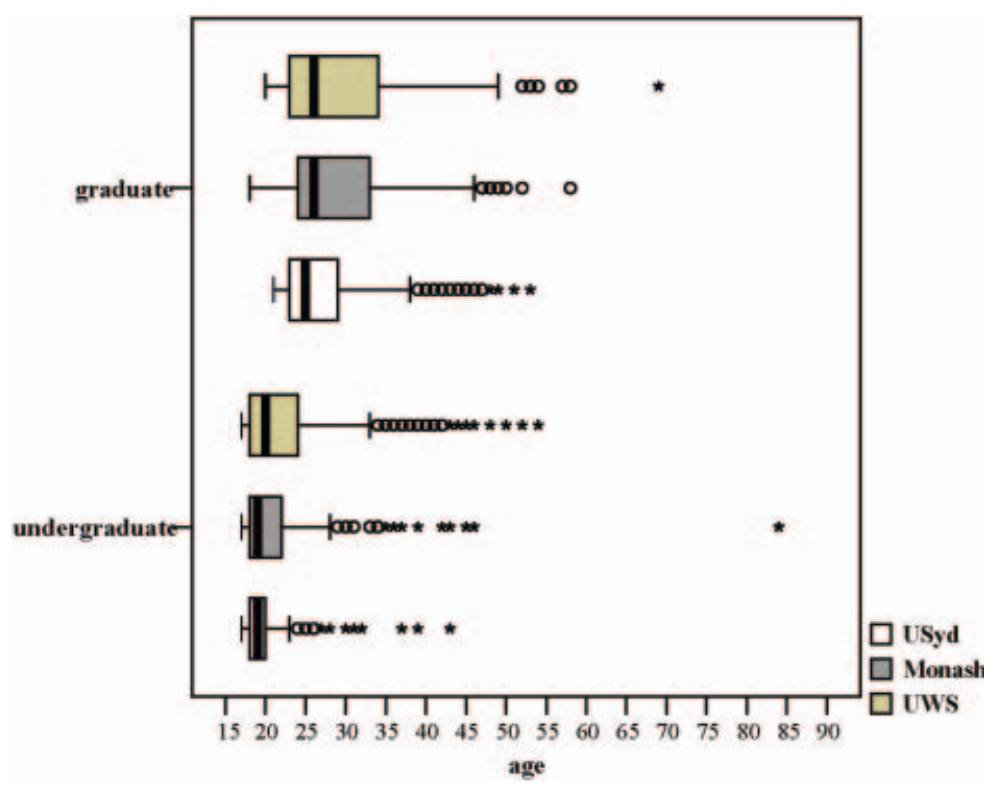

Figure 2. Age profiles for beginning teacher education candidates

Note. The box length is the interquartile range and the solid bar represents the median value. "o" denotes outliers with values between 1.5 and three box lengths from the upper or lower edge of the box, "*" denotes extreme cases with values more than three box lengths from the upper or lower edge of the box. 
(interquartile range from 23 to 34 years), with Monash again falling in between (interquartile range from 24 to 33 years).

SES income backgrounds. The median and modal participant-reported combined parent income category was $\$ 60,001-90,000$. This held for undergraduate and graduate participants across each of the three universities. All distributions were positively skewed, indicating that a greater concentration of participants came from the lower parent income categories provided for on the survey, although there were differences between graduates and undergraduates in the spread of parent income profiles. For graduates, the distribution for this SES background indicator was remarkably similar across universities (see Figure 2). The interquartile range in each case was from $\$ 30,001-60,000$ to $\$ 90,001-120,000$, while the box plot "whiskers" ranged from $\$ 0-30,000$ to $\$ 180,001-210,000$, with few outliers in the two highest income brackets. For undergraduates, the distributions were both different from graduates, as well as different across universities. At UWS, the distribution for undergraduate participants' combined parent income was highly kurtotic and positively skewed, with $50 \%$ of this group reporting between $\$ 30,001-60,000$ and

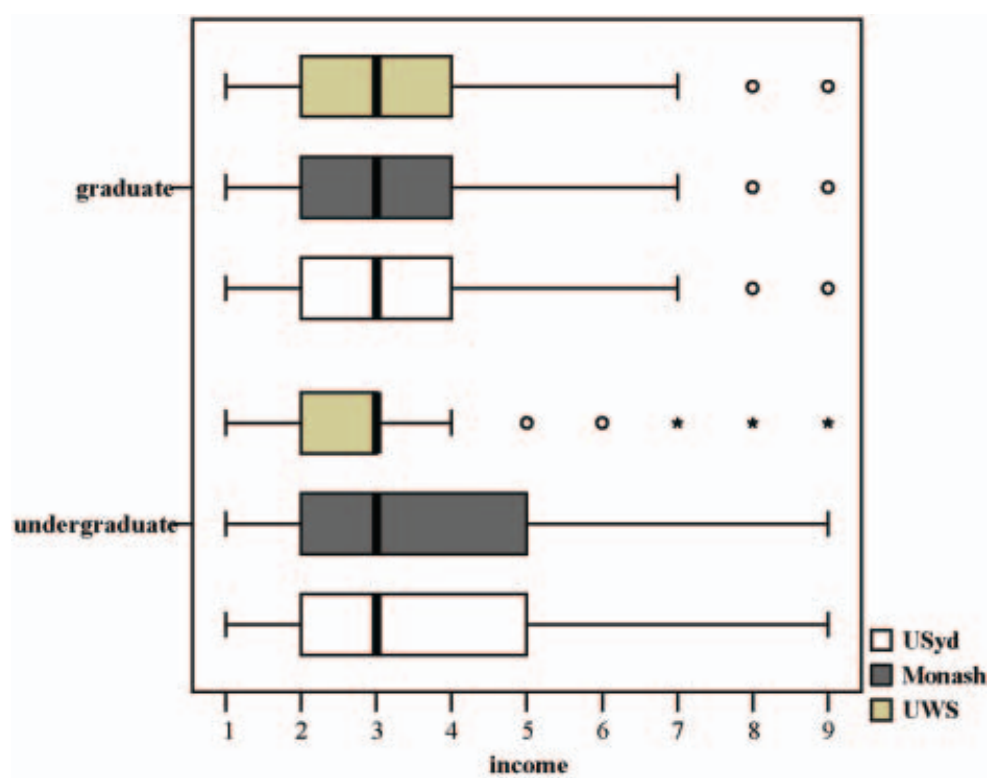

Figure 3. Combined parent income for beginning teacher education candidates (indicative SES)

Notes. Income values: 1 : $\$ 0-30,000,2: \$ 30,001-60,000,3: \$ 60,001-90,000,4: \$ 90,001-120,000$, 5: $\$ 120,001-150,000,6$ : $\$ 150,001-180,000,7$ : $\$ 180,001-210,000,8: \$ 210,001-240,000$, 9: $\$ 240,000+$.

The box length is the interquartile range and the solid bar represents the median value. "o" denotes outliers with values between 1.5 and three box lengths from the upper or lower edge of the box, “*” denotes extreme cases with values more than three box lengths from the upper or lower edge of the box. 
$\$ 60,001-90,000$. The box plot whiskers spanned $\$ 0-30,000$ to $\$ 90,001-120,000$, with few outliers and extreme cases reporting any of the higher parent income brackets. The middle 50\% concentration of UWS undergraduates therefore reported coming from less diverse and lower SES income backgrounds than the graduates. In contrast, at both the University of Sydney and Monash University, undergraduate participants reported greater variation for this SES background indicator than the graduates. For both the University of Sydney and Monash University, the undergraduate interquartile range reached from $\$ 30,001-60,000$ to $\$ 120,001$ 150,000 , while the box plot whiskers spanned from $\$ 0-30,000$ through to the highest $\$ 240,000+$ category. Undergraduate participants from the University of Sydney and Monash University therefore come from a greater range of SES income backgrounds-where this increased range reaches upwards into higher parent income brackets. The reverse is true at UWS, where undergraduates come from a more compressed range at the lower end of the parent income bracket.

\section{Ethnic Backgrounds}

English was overwhelmingly the home language for undergraduates and graduates within each university. Proportions were similar at the University of Sydney (82\%) and UWS (81\%). The proportion was slightly higher at Monash, with $90 \%$ of participants listing English as their home language. Other nominated home languages were from around the world, and differed across the three universities. The languages for which representation exceeded one percent were:

- University of Sydney: Korean $2 \%$, Chinese $4 \%$, Greek $2 \%$;

- Monash University: Japanese $2 \%$, Chinese $2 \%$; and

- UWS: Arabic 6\%, Chinese 2\%, Hindi $2 \%$.

Chinese (Cantonese, Hokkien and Mandarin) was the only language apart from English which had representation greater than one percent across all three universities. As shown above, other than Chinese, each university had different language speakers with representations exceeding $1 \%$. Other home languages had negligible representations.

Most participants' parents were born in Australia relative to any other country: $53 \%$ of fathers and $59 \%$ of mothers at the University of Sydney, $56 \%$ of fathers and $60 \%$ of mothers at Monash University, and $47 \%$ of fathers and $50 \%$ of mothers at UWS. The next most common parent country of birth was the UK. Representations exceeded one percent for parents' country of origin for:

- University of Sydney: UK (fathers $9 \%$, mothers $6 \%$ ), Italy (fathers $4 \%$, mothers $3 \%$ ), Greece (fathers 3\%, mothers $2 \%$ ), Lebanon (fathers 3\%, mothers $2 \%$ ), China (fathers $2 \%$, mothers $2 \%$ ), Hong Kong (fathers $2 \%$, mothers $3 \%$ ), and Korea (fathers $2 \%$, mothers $2 \%$ ). 
- Monash: UK (fathers $9 \%$, mothers $10 \%$ ), Italy (fathers 3\%), Japan (fathers 3\%, mothers 3\%), and Greece (fathers $2 \%$, mothers $2 \%$ ).

- UWS: UK (fathers $8 \%$, mothers $8 \%$ ), Lebanon (fathers $6 \%$, mothers $6 \%$ ), Canada $^{4}$ (fathers $3 \%$, mothers $4 \%$ ), China (fathers $2 \%$ ), Egypt (fathers $2 \%$, mothers $2 \%$ ), Fiji (fathers $2 \%$, mothers $2 \%$ ), Greece (mothers $2 \%$ ), India (mothers $2 \%$ ), and Italy (fathers $2 \%$ ).

"Career switcher" backgrounds. Slightly over a third of graduate participants from each university indicated that they had previously pursued another career prior to entering teacher education (34\% of graduates at the University of Sydney, $43 \%$ at Monash and 35\% at UWS). Previous careers spanned a diverse range, represented in Figures $4 \mathrm{a}$ through $4 \mathrm{c}$ for the University of Sydney, Monash and UWS. The most common career backgrounds at the University of Sydney, with greater than $10 \%$ representation, related first to entertainment, followed by science and management. At Monash the most common career backgrounds were in science, while at UWS they were again entertainment followed by information technology.

The occupational status of career switchers' previous careers was predominantly on par with teaching as shown in Figure 5: 51\% of career switchers at the University of Sydney, $62 \%$ at Monash and $51 \%$ at UWS had changed careers into teaching from occupations classified as at the same level of occupational status (US Department of Labor Employment and Training Administration, 1998). At the University of Sydney and Monash, few career switchers had come from career backgrounds of lower status than teaching $(21 \%$ at the University of Sydney and $15 \%$ at Monash), with approximately a quarter of them switching down from careers higher in occupational status than teaching $(28 \%$ at the University of Sydney and $23 \%$ at Monash). This pattern was reversed at UWS, where more people had switched upward in occupational status from their prior careers $(28 \%)$ than had switched downward from higher status careers $(21 \%)$.

\section{Why Choose Teaching?}

Motivations for teaching. Highest rated motivations for choosing teaching included perceived teaching abilities, the intrinsic value of teaching, and the desire to make a social contribution, shape the future, and work with children/adolescents (see Figures $6 \mathrm{a}$ and $6 \mathrm{~b}$ ). The lowest rated motivation was choosing teaching as a "fallback" career, followed by social influences of others encouraging them to undertake teaching as a career. Other motivations were rated in between for the desire to enhance social equity, having experienced positive prior teaching and learning experiences, job security, job transferability, and time for family. Figure 6a presents mean ratings for each motivation for undergraduates within each university, and Figure $6 \mathrm{~b}$ depicts mean ratings for graduate participants within each university. 


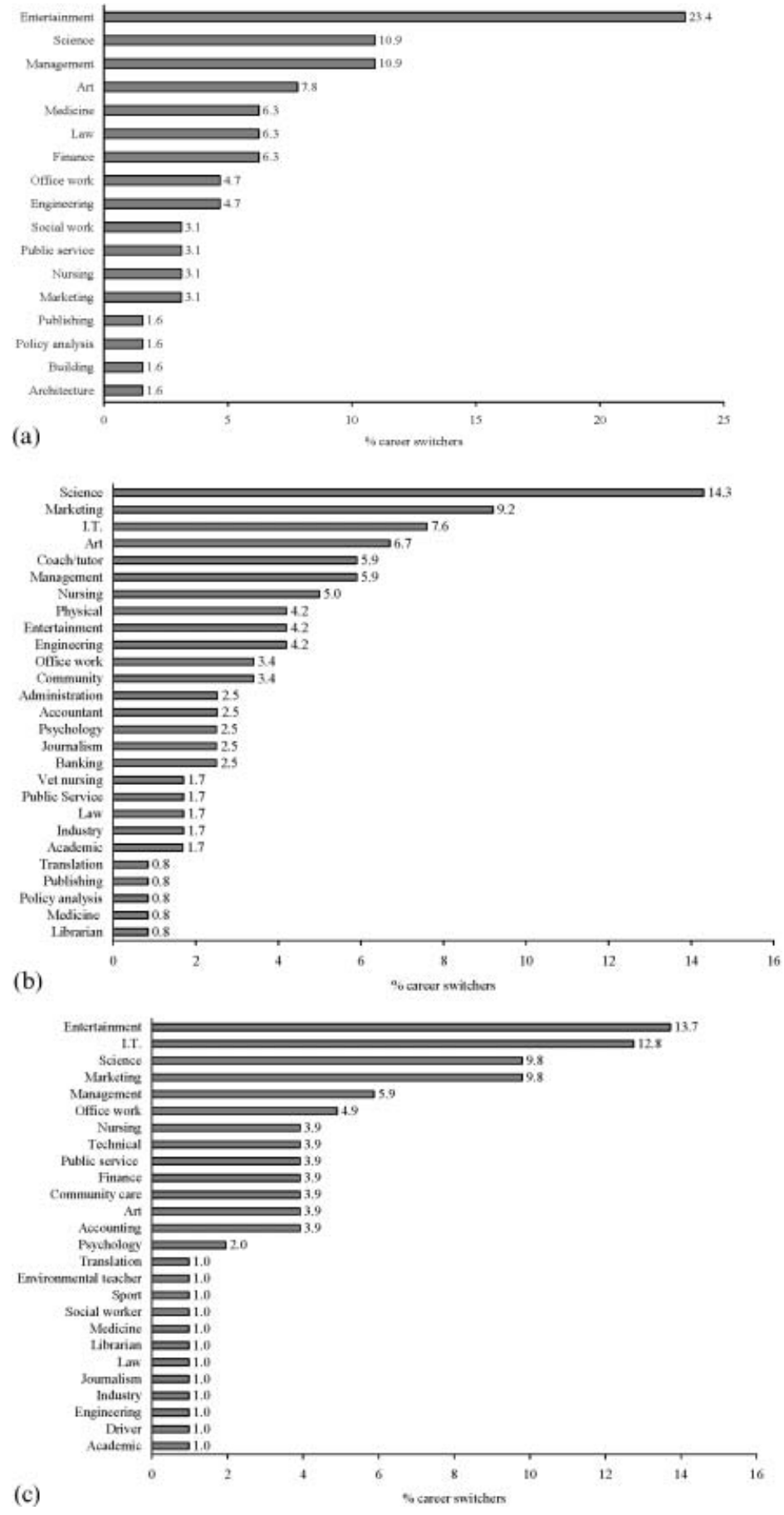

Figure 4a. Graduate entry career switchers: University of Sydney (34\%)

4b. Graduate entry career switchers: Monash University (43\%)

4c. Graduate entry career switchers: University of Western Sydney (35\%) 


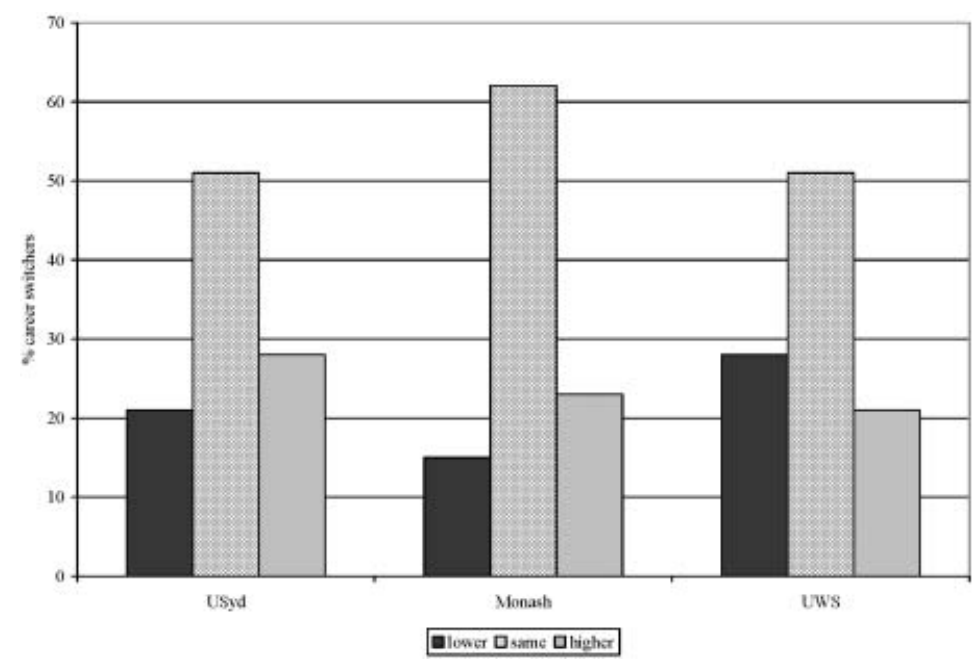

Figure 5. Graduate entry career changers: previous job status relative to teaching

Few systematic differences were evident between the teaching motivations for undergraduate and graduate participants across the three universities (see Table 5). At the University of Sydney, statistically significant differences occurred for four motivations: undergraduates scored higher on job security, time for family, and positive prior teaching and learning experiences; while graduates had higher ratings for the desire to make a social contribution. At Monash, undergraduates gave statistically significantly higher ratings for the intrinsic value of teaching and desire to work with children/adolescents. At UWS, undergraduates also rated statistically significantly higher their desire to work with children/adolescents, while-similarly to the University of Sydney-graduates rated statistically significantly higher their desire to make a social contribution.

Perceptions about the profession. Participants generally perceived teaching as a career which is high in demand-and low in return. Figure 7 summarizes the mean ratings for undergraduates and graduates within each university. Participants rated teaching as a highly demanding career in terms of having a heavy workload, high emotional demand and generally requiring hard work. They also rated teaching as a highly expert career, in terms of requiring high levels of specialized and technical knowledge. At the same time, participants generally perceived teaching as relatively low in social status, and as paying a low salary. Again there were few systematic differences between undergraduate and graduate participants' perceptions when these were assessed within each university (Table 5). At the University of Sydney, graduates rated teaching statistically significantly higher for expert career and high demand, while undergraduates gave statistically significantly higher ratings for social status and salary. At Monash, graduates also rated teaching as statistically significantly higher in demand, while under- 

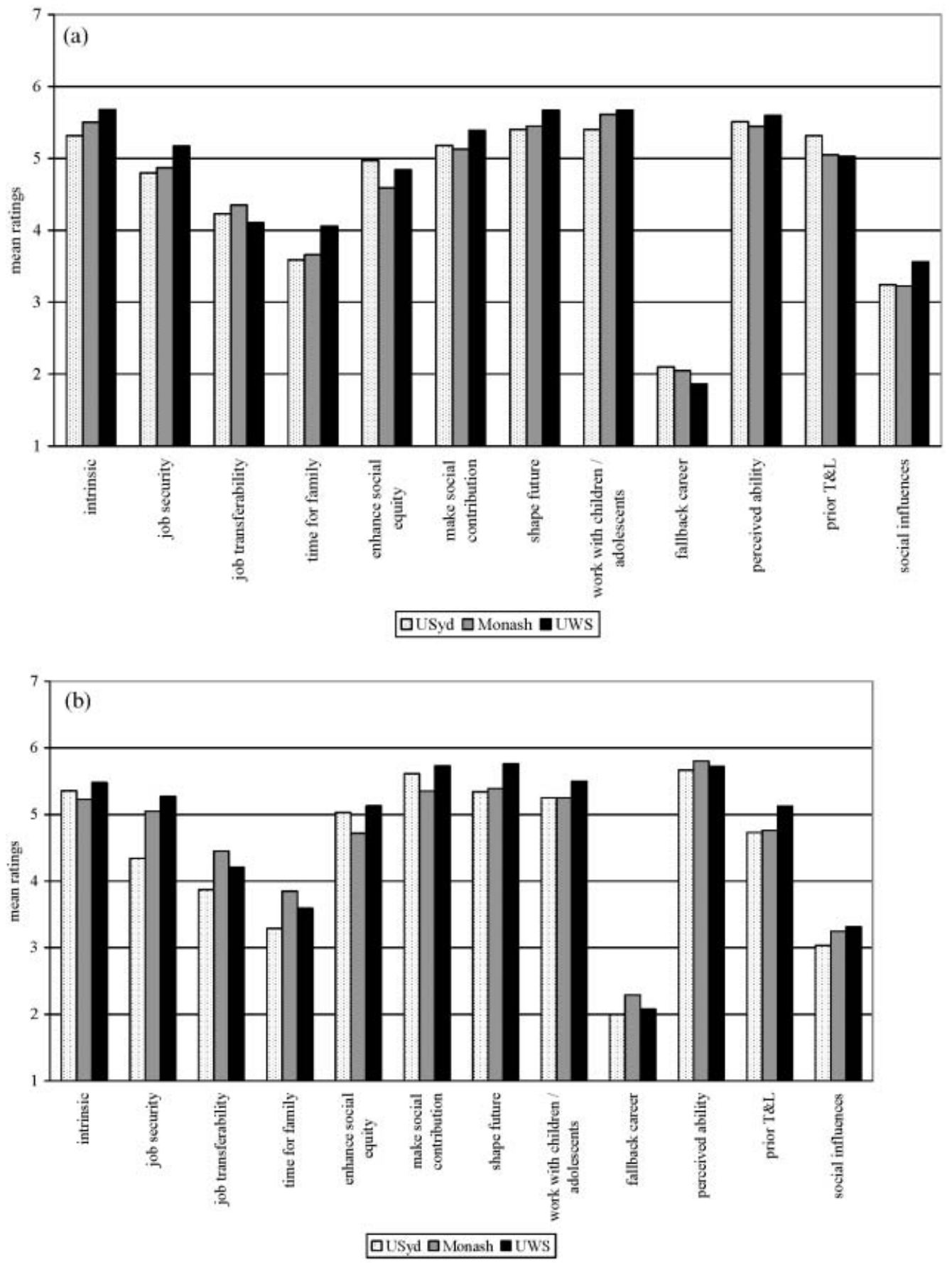

Figure 6a. Factors influencing teaching choice for undergraduates $6 \mathrm{~b}$. Factors influencing teaching choice for graduates 
Table 5. Different teaching motivations and perceptions for undergraduates versus graduates (statistically significant differences are listed)

\begin{tabular}{|c|c|c|c|c|c|c|c|c|c|}
\hline & \multicolumn{3}{|c|}{ USyd } & \multicolumn{3}{|c|}{ Monash } & \multicolumn{3}{|c|}{ UWS } \\
\hline & $\mathrm{UG} M(S D)$ & Grad $M(S D)$ & F-value & UG $M(S D)$ & $\operatorname{Grad} M(S D)$ & F-value & UG $M(S D)$ & Grad $M(S D)$ & F-value \\
\hline \multicolumn{10}{|c|}{ Factors influencing teaching choice } \\
\hline Intrinsic & - & - & - & $5.4(1.1)$ & $5.2(1.1)$ & $\mathrm{F}(1,501)=7.5$ & - & - & - \\
\hline Job security & $4.8(1.4)$ & $4.4(1.5)$ & $\mathrm{F}(1,482)=10.9$ & - & - & - & - & - & - \\
\hline Time for family & $4.0(1.4)$ & $3.3(1.5)$ & $\mathrm{F}(1,479)=26.6$ & - & - & - & - & - & - \\
\hline Prior T\&L & $5.3(1.4)$ & $4.7(1.7)$ & $\mathrm{F}(1,482)=17.2$ & - & - & - & - & - & - \\
\hline $\begin{array}{l}\text { Make social } \\
\text { contribution }\end{array}$ & $5.2(1.3)$ & $5.6(1.2)$ & $\mathrm{F}(1,484)=12.6$ & - & - & - & $5.4(1.3)$ & $5.7(1.1)$ & $\mathrm{F}(1,643)=10.7$ \\
\hline \multirow{2}{*}{$\begin{array}{l}\text { Work with } \\
\text { children/ } \\
\text { adolescents }\end{array}$} & - & - & - & $5.6(1.3)$ & $5.2(1.4)$ & $F(1,499)=9.5$ & $5.7(1.2)$ & $5.4(1.4)$ & $\mathrm{F}(1,642)=10.7$ \\
\hline & \multicolumn{9}{|c|}{ Perceptions about teaching } \\
\hline $\begin{array}{l}\text { Expert } \\
\text { career }\end{array}$ & $5.2(1.1)$ & $5.5(1.1)$ & $\mathrm{F}(1,482)=11.1$ & - & - & - & - & - & - \\
\hline $\begin{array}{l}\text { High } \\
\text { demand }\end{array}$ & $5.8(0.9)$ & $6.2(0.7)$ & $\mathrm{F}(1,485)=39.2$ & $5.9(0.8)$ & $6.3(0.7)$ & $\mathrm{F}(1,503)=32.3$ & - & - & - \\
\hline $\begin{array}{l}\text { Social } \\
\text { status }\end{array}$ & $3.9(1.1)$ & $3.3(1.1)$ & $\mathrm{F}(1,481)=36.5$ & $4.5(1.2)$ & $3.8(1.2)$ & $\mathrm{F}(1,499)=36.4$ & - & - & - \\
\hline Salary & $3.2(1.2)$ & $2.5(1.2)$ & $\mathrm{F}(1,483)=37.4$ & - & - & - & - & - & - \\
\hline
\end{tabular}


graduates rated the social status of teaching significantly more highly than graduates. There were no statistically significant differences at UWS between undergraduate and graduate participants' ratings for their perceptions about the teaching profession.

Career choice satisfaction. Interestingly, teacher education entrants reported relatively strong experiences of social dissuasion from teaching as a career (mean ratings around the scale midpoint, see Figure 7). These experiences were similarly strong for undergraduates and graduates within each university. Despite this, and despite perceptions of teaching as a career high in demand and low in return, mean satisfaction ratings for teaching as a career choice were uniformly high (see Figure 7). There were also no significant differences in satisfaction with teaching as a career choice between undergraduates and graduates at any of the three universities.

\section{Discussion}

Our study has profiled teacher education entrants' characteristics, motivations for choosing teaching, perceptions about the profession and career choice satisfaction across three Australian universities, all of them major teacher education providers. For this sample of pre-service teachers, their decision to enrol in a teacher education program has been made at a time when the mass media and the general public have increasingly

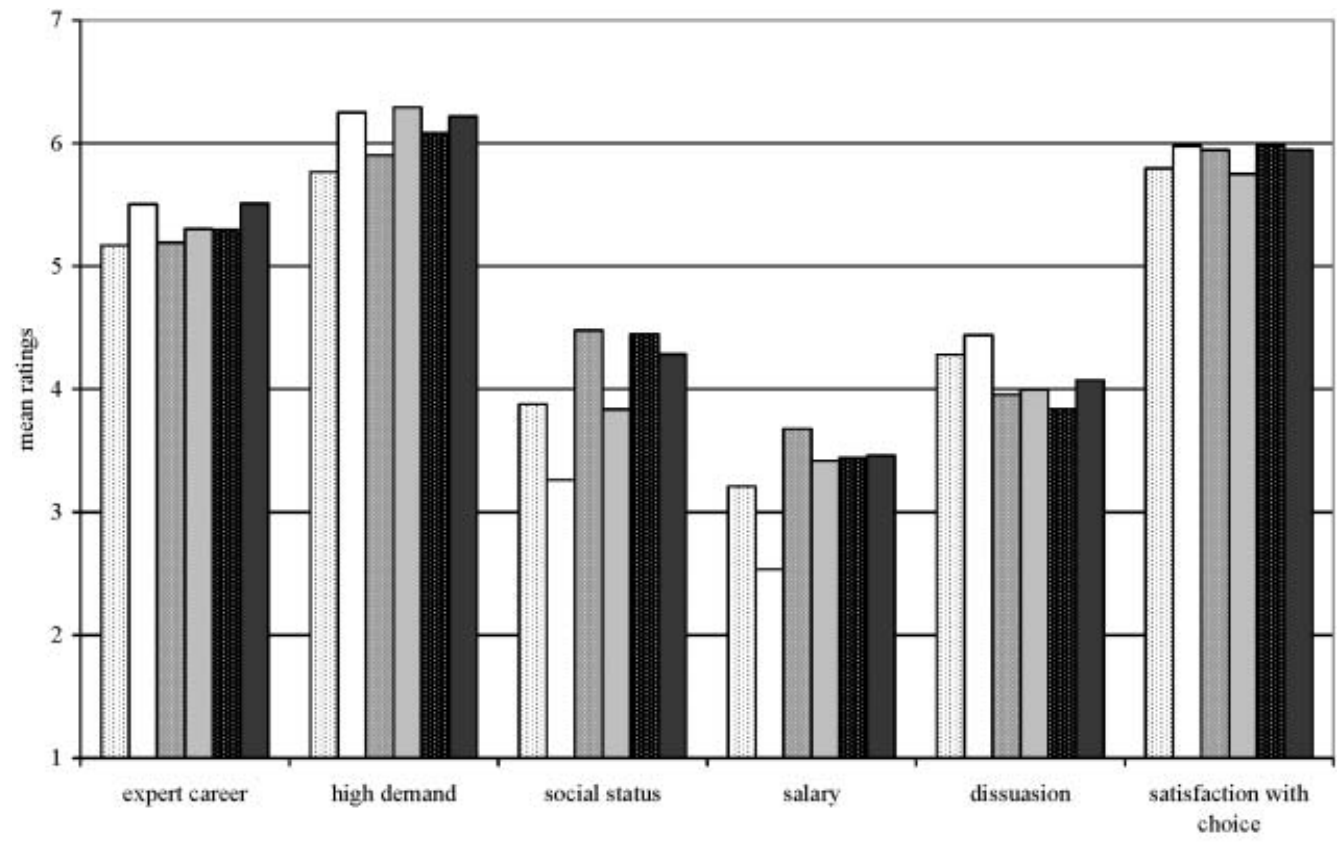

GUSyd UG QUSyd grad DMonash UG QMonash grad is UWS UG QUWS grad

Figure 7. Perceptions about teaching 
looked upon teaching as a poor career choice. Our findings will help direct effective recruitment efforts through a better understanding of who chooses teaching and why.

\section{Who Chooses Teaching?}

Far greater numbers of females than males enrolled in teacher education, in tune with current concerns about the lack of males entering teaching. This was most marked for early childhood teacher education which had almost exclusively female enrolments, followed by primary teacher education, and then by secondary teacher education. Should the lack of males in teacher education be considered a problem in terms of a lack of male role models (see DEST, 2003), this issue may be particularly acute in relation to the gender imbalance for prospective teachers of young children. In general, pre-service teachers were quite young-the median age for undergraduates was the "school-leaver" age of 19 to 20, while for graduates it was 25 to 26 years old. There was greater variation among the ages of graduate pre-service teacher education candidates than among the undergraduates, with the University of Sydney having the least age variations and UWS the most.

SES income backgrounds for prospective teachers were generally towards the lower region of the income categories, with few participants coming from affluent family income backgrounds. This was especially true for graduate participants, for whom there was less variation in SES family income background than for undergraduates - except in the case of UWS where undergraduate candidates were quite homogeneous in their SES income background and concentrated towards the lower end of the measured income spectrum. English was the dominant home language for pre-service teachers, and around half the participants' parents were born in Australia, with approximately one-tenth born in the UK, and smaller proportions from other countries around the world.

Career switchers into teaching comprised over a third of the graduate sample at each of the universities, with these participants coming from a diversity of previous career backgrounds, although most frequently from entertainment, science and information technology fields. These findings may suggest fruitful career domains to which teacher recruitment campaigns could advantageously market. In terms of the relative occupational status of career switchers' prior careers to teaching, more than half came from careers on par with teaching. UWS had the highest concentration of career switchers from lower occupational status careers, also being a higher proportion than those switching into teaching from higher status careers-the reverse of the pattern at the University of Sydney and Monash University.

These background characteristics for participants together paint a broad portrait of beginning teacher education candidates as typically female, young, from less than affluent family backgrounds, English speaking, and born of Australian parents. A sizeable proportion of graduate teacher education candidates have had previous careers from which they have "switched" into teaching, most often of similar occupational status. 


\section{Why Choose Teaching?}

Counter to much earlier findings (Haubrich, 1960), teaching was not typically considered a "fallback" career-either for graduate or undergraduate participants. Regardless of the evidence, these claims continue to circulate in the public media and in uninformed opinion. Nor was encouragement from others a strong factor in individuals' choice of teaching as a career. Participants' teaching ability-related beliefs, personal and social utility values and positive prior experiences of teaching and learning were all important motivations for choosing teaching as a career. Values included the intrinsic value of teaching, social utility values (including the desire to shape the future, enhance social equity, make a social contribution and work with children/adolescents), and then personal utility values (these included job security, time for family and job transferability).

Participants perceived teaching as a career that is highly demanding, and one that provides for low return in terms of salary and social status. The fact that these potential entrants into teaching rated the intrinsic value of teaching highly despite this, suggests that teaching may afford different types of rewards that are not always inherent in other occupations, and that participants seek out those rewards that come from the experience of teaching, and the opportunity structure which teaching affords to provide for the realization of their personal and social values. This is reflected through participants simultaneously reporting uniformly high levels of satisfaction with their choice of teaching as a career. In workplace circumstances where these kinds of rewards become swamped by other more immediate and pressing demands, teachers may be less likely to persist in the profession. Knowing that a career is demanding is quite different to actually "living" the experience of the lack of comparative rewards such as salary and status, that other equally demanding careers offer (Liu et al., 2000). Those "rewards" provided by careers other than teaching may become increasingly attractive during the "lived" experience of beginning teaching. While Australian entry level salaries for teachers are comparable with other similarly skilled careers, salary scales significantly plateau after five to ten years of teaching service (MCEETYA, 2002). Other recent studies have indeed found that low teaching salaries and the contrasting rewards for comparable jobs do exert an influence on individuals' decisions to leave the teaching profession (see Liu et al., 2000; OECD, 2004; Ramsay, 2000).

Participants reported relatively strong experiences of social dissuasion from teaching. For whatever reason, others had advised them not to go into teaching. Whereas earlier research found that previous teachers and family had been frequently nominated as influences on the choice of teaching as a career (Book \& Freeman, 1986; Fox, 1961; Lortie, 1975; Robertson, Keith, \& Page, 1983), our measurement of the importance of this factor, relative to a range of others, showed that in this sample significant others were not highly influential in general, with mean ratings well below the scale midpoint. Importantly, all these perceptions were assessed near the beginning of participants' first year of teacher educationindicating that they have chosen teaching as a career despite their perceptions about 
the relative demands and returns in the profession, and despite their experiences of others attempting to dissuade them from teaching as a career.

There were few systematic differences between undergraduate and graduate participants across the three universities, implying that motivations for choosing teaching as a career tend to be unrelated to whether participants chose teaching as their initial career or not. Significantly, undergraduates and graduates had similar levels of satisfaction with teaching as a career choice within each of the three universities, implying that graduate entrants are not necessarily more contented with and committed to their choice of a teaching career, as has been suggested in smaller scale studies based on more opportune samples (Crow et al., 1990; Freidus, 1992; Priyadharshini \& Robinson-Pant, 2003).

\section{Implications for Policy and Practice}

The characteristics of those people choosing to enter teacher education in the current climate of teacher shortages provide valuable background information for policy-makers, recruitment bodies, university governance and teacher educators. Our robust empirical findings regarding those motivations which have attracted these people to pursue teaching careers will be of particular use to these groups. Current and recent recruitment campaigns have tended to focus on a limited subset of these motivations, predominantly relating to the opportunity to make a social contribution and the opportunity to work with children, likely limiting their audience and effectiveness. An expanded focus which includes additional social utility values (opportunities to shape the future and enhance social equity), as well as personal utility values (job security, time for family, job transferability), intrinsic values and individuals' perceptions regarding their teaching-related abilities, promises to yield more effective results. Results from our study indicate that people are attracted to teaching as a career mainly because they perceive themselves as having the abilities to teach well, they believe they will find teaching an intrinsically rewarding and enjoyable occupation, they have themselves enjoyed positive learning experiences, they perceive teaching will provide them with a high level of job security, and to be a worthwhile job that has the potential to influence the quality of life for others, especially children and adolescents. Additionally, the opportunity to balance career with quality of life concerns is important. This profile of motivations for people entering teacher education programs in three Australian universities suggests that we should not be focused on a limited number of values, such as working with children and making a social contribution. Instead, it is clear that a range of values are important. We therefore argue that it is essential to target the multiplicity of factors that together impact the decision to enter teaching as a career.

\section{Our Ongoing Program of Research}

Teacher education has been subjected to a significantly large number of reviews over the last thirty years (Dyson, 2005) and yet we struggle to understand why people are 
attracted into teaching in the first place and why they are either retained or leave the profession. Such a situation would suggest that we need a different approach to teacher recruitment, induction and retention. This study has reported on the first phase of our ongoing longitudinal research program targeting recruitment, induction and retention issues, across universities in Australia and the US. We are also currently collaborating with colleagues at the Max Planck Institute for Human Development (Berlin, Germany) who have implemented our FIT-Choice Scale, to provide information from the context of a very different schooling system. These further samples from outside of Australia will allow us to more effectively chart general trends, and to place local particularities into broader contexts of development for a career that Governments around the world continue to acknowledge as central to social and economic well-being. Our three-phase study tracks the same participants, from their entry into teacher education, again at the point of graduation from their teacher education program, and then two years following graduation. Phase 2 of this research program is currently underway, in which we assess graduands' teaching self-efficacy and professional commitment prior to their entry into the teaching profession. Phase 3 will focus on participants in their early years in the profession (or outside the teaching profession if they have not entered teaching or decided to leave the profession), with a focus on beginning teacher mentoring, teaching self-efficacy and professional commitment, levels of stress and burnout, and contextual school environment features. Relational pathways across Phases 1 to 3 will provide the first study to track identified individual teacher developmental pathways within a methodologically sophisticated, large-scale and international longitudinal design.

\section{Acknowledgements}

Preparation of this paper was supported in part by institutional grants from the University of Western Sydney, the University of Sydney, and Monash University. We wish to thank Dr Ray Debus from the University of Sydney for his suggestions and feedback on an earlier version of the paper, and Professor Jacquelynne Eccles from the University of Michigan for valuable discussions about our ideas.

\section{Notes on Contributors}

The authors together with Jacquelynne S. Eccles (University of Michigan) hold an Australian Research Council Discovery Grant 2006-9 for their ongoing "FITChoice" research program.

Paul W. Richardson is a visiting Research Scientist at the University of Michigan, working on a National Institute Child Health and Human Development (NICHD) funded study.

Helen M. G. Watt has previously been Faculty at Macquarie, Sydney, and UWS universities and is currently a Research Scientist at the University of Michigan. 


\section{Notes}

1. This factor includes items which tap the extent to which teaching provides time for individuals to pursue other activities (for example, length of vacations, length of working day). Those items were initially designed to tap a "bludging" factor (an Australianism which refers to expending the least effort possible), which interestingly was empirically indistinguishable from the items tapping the extent to which teaching provides for family time (for example, fitting with family commitments, allowing for more family time). Rather than signaling the pejorative "bludging", it appears that individuals who rate vacation times and working hours as important to their choice of teaching as a career are making these judgments in relation to significant quality of life considerations.

2. From 2005, UWS is now offering teacher education programs solely in graduate mode.

3. Applicable to Monash University and the University of Western Sydney undergraduates only.

4. UWS actively recruits graduate teacher education candidates from the Ontario Institute for Studies in Education at the University of Toronto.

\section{References}

Beck, U. (2000). The brave new world of work. (R.Camiller, Trans.). Cambridge: Polity Press.

Book, C. L., \& Freeman, D. J. (1986). Differences in entry characteristics of elementary and secondary teacher candidates. Fournal of Teacher Education, 37(2), 47-51.

Brown, M. M. (1992). Caribbean first-year teachers' reasons for choosing teaching as a career. fournal of Education for Teaching, 18(2), 185-195.

Bullough Jr., R. V., \& Knowles, J. G. (1990). Becoming a teacher: Struggles of a second career beginning teacher. International fournal of Qualitative Studies in Education, 3(2), 101-112.

Crow, G. M., Levine, L., \& Nager, N. (1990). No more business as usual: Career changers who become teachers. American fournal of Education, 98, 197-223.

DEST. (2003). Australia's teachers: Australia's future. Advancing innovation, science, technology and mathematics. Canberra: Committee for the review of teaching and teacher education, Department of Education, Science and Training.

Dyson, M. (2005). Australian teacher education: Although reviewed to the eyeballs is there evidence of significant change and where to now?. Australian fournal of Teacher Education, 30(1), 37-54.

Eccles (Parsons), J., Adler, T. F., Futterman, R., Goff, S. B., Kaczala, C. M., \& Meece, J. L., et al. (1983). Expectancies, values, and academic behaviors. In J. T. Spence (Ed.), Achievement and achievement motivation (pp. 75-146). San Francisco, CA: W.H. Freeman.

European Commission. (2000). Key data on education in Europe. European Commission: Brussels.

Fox, R. B. (1961). Factors influencing the career choice of prospective teachers. fournal of Teacher Education, 7(4), 427-432.

Freidus, H. (1992, April). Men in women's world: A study of male second career teachers in elementary schools. Paper presented at the annual meeting of the American Educational Research Association, San Francisco, CA.

Haipt, M. (1987/1988). Choosing teaching as a mid-career change. The Teacher Educator, 23(3), $17-24$.

Haubrich, V. F. (1960). The motives of prospective teachers. Fournal of Teacher Education, 11(3), 381-386.

Henke, R. R., Chen, X., \& Geis, S. (2000). Progress through the teacher pipeline: 1992-93 college graduates and elementary/secondary school teaching as of 1997. Washington, DC: National Center for Educational Statistics. 
House of Representatives Standing Committee on Education and Training. (2002). Boys: Getting it right. Canberra, Australia.

Johnson, S. M., \& Birkeland, S. E. (2003). Pursuing a "sense of success": New teachers explain their career decisions. American Educational Research fournal, 40(3), 581-617.

Lent, R. W., Lopez, F. G., \& Bieschke, K. J. (1993). Predicting mathematics-related choice and success behaviors: Test of an expanded social cognitive model. Fournal of Vocational Behavior, 42, 223-236.

Lingard, B., Martino, W., Mills, M., \& Bahr, M. (2002). Addressing the educational needs of boys. Canberra, Australia: Report to Department of Education, Science and Training.

Liu, E., Kardos, S. M., Kauffman, D., Preske, H. G., \& Johnson, S. M. (2000). Barely breaking even: Incentives, rewards, and the high costs of choosing to teach. Cambridge: Harvard Graduate School of Education.

Lokan, J., Ford, P., \& Greenwood, L. (1996). Maths \& science on the line: Australian junior secondary students' performance in the third international mathematics and science study. Melbourne: Australian Council for Educational Research.

Lortie, D. C. (1975). School-teacher: A sociological study. Chicago: University of Chicago Press.

Ludwig, M., Stapleton, L., \& Goodrich, B. (1995). Sustaining the supply of math and science teachers: Assessing the long-term effects of nontraditional and mid-career teacher preparation programs. Washington, DC: American Association of State Colleges and Universities.

Martin, A. J. (2002). Improving the educational outcomes of boys. Canberra: Report to ACT Department of Education, Youth and Family Services.

MCEETYA. (1999). The Adelaide declaration on national goals for schooling in the twenty-first century. Melbourne: Ministerial Council on Employment, Education, Training and Youth Affairs (MCEETYA).

MCEETYA. (2002). Demand and supply of primary and secondary school teachers in Australia. Melbourne: Ministerial Council on Education, Employment, Training and Youth Affairs.

Moran, A., Kilpatrick, R., Abbott, L., Dallatt, J., \& McClune, B. (2001). Training to teach: Motivating factors and implications for recruitment. Evaluation $\mathcal{E}$ Research in Education, 15(1), 17-32.

Novak, D., \& Knowles, G. J. (1992, April). Life histories and the transition to teaching as a second career. Paper presented at the Annual meeting of the American Educational Research Association, San Francisco, CA.

OECD. (2004). Attracting, developing and retaining effective teachers. Retrieved December 14, 2005 from http://www.oecd.org/document/9/0,2340,en_2649_34521_11969545_1_1_1_1,00.html.

Ofsted. (2001). The annual report of Her Majesty's Chief Inspector of Schools: Standards and quality in education 2000/01. London: Office of Standards in Education.

Ornstein, A. C., \& Miller, H. L. (1980). Looking into teaching: An introduction to American education. Chicago: Rand McNally College Publishing Company.

Powell, R. R. (1996). Teaching alike: A cross-case analysis of first career and second career beginning teachers' instructional convergence. Teaching and Teacher Education, 13(3), 341-355.

Preston, B. (2000). Teacher supply and demand to 2005: projections and context. Canberra: Australian Council of Deans.

Priyadharshini, E., \& Robinson-Pant, A. (2003). The attraction of teaching: an investigation into why people change careers to teach. Fournal of Education for Teaching: International Research and Pedagogy, 29(2), 95-112.

Ramsay, G. (2000). Quality matters. Revitalising teaching: Critical times, critical choices. Report of the review of teacher education. Sydney: NSW Department of Education and Training.

Resta, V., Huling, L., \& Rainwater, N. (2001). Preparing second-career teachers. Educational Leadership, 13(3), 60-63. 
Richardson, P. W., \& Watt, H. M. G. (2003, 17-20 September). Rethinking research into the choice of teaching as a career: Application of a new theoretical approach. Paper presented at the European Conference on Educational Research, Hamburg, Germany.

Richardson, P. W., \& Watt, H. M. G. (2005). "I've decided to become a teacher": Influences on career change. Teaching \& Teacher Education, 21, 475-489.

Robertson, S., Keith, T., \& Page, E. (1983). Now who aspires to teach? Educational Researcher, 12(6), 13-21.

Santiago, P. (2001). Teacher shortage. OECD Observer. Retrieved December 14, 2005, from http://www.oecdobserver.org/news/printpage.php/aid/431/Teacher-shortage.html.

Serow, R. C., \& Forrest, K. D. (1994). Motives and circumstances: Occupational-change experiences of prospective late-entry teachers. Teaching \& Teacher Education, 10(5), 555-563.

Skilbeck, M., \& Connell, H. (2003). Attracting, developing and retaining effective teachers: Australian country background report. Canberra, ACT: Department of Education, Science and Training.

US Department of Labor Employment and Training Administration. (1998). O^NET: The occupational information network. Washington, DC: US Government Printing Office.

Watt, H. M. G. (2002). Gendered achievement-related choices and behaviours in mathematics and English: The nature and influence of self-, task- and value perceptions. Unpublished $\mathrm{PhD}$ thesis, University of Sydney.

Watt, H. M. G., \& Richardson, P. W. (2003, 17-20 September). Teaching as a gendered profession: The application of expectancy-value theory to understanding gendered motivations for teaching as a career choice. Paper presented at the European Conference on Educational Research, Hamburg, Germany.

Watt, H. M. G., \& Richardson, P. W. (in review). Motivational factors influencing teaching as a career choice: Development and validation of the "FIT-Choice" Scale. Fournal of Educational Psychology.

Wigfield, A., \& Eccles, J. S. (2000). Expectancy-value theory of achievement motivation. Contemporary Educational Psychology, 25, 68-81. 